\title{
Synthesis, Structure and In Vitro Anticancer Activity of Pd(II) Complex of Pyrazolyl-s-Triazine Ligand; A New Example of Metal-Mediated Hydrolysis of $s$-Triazine Pincer Ligand
}

\author{
Jamal Lasri 1,*(D), Matti Haukka ${ }^{2}$ (D), Hessa H. Al-Rasheed ${ }^{3}$, Nael Abutaha ${ }^{4}$, Ayman El-Faham ${ }^{3,5, *(D)}$ and \\ Saied M. Soliman $5, *$ (D) \\ 1 Department of Chemistry, Rabigh College of Science and Arts, King Abdulaziz University, P.O. Box 344, \\ Jeddah 21589, Saudi Arabia \\ 2 Department of Chemistry, University of Jyväskylä, P.O. Box 35, FI-40014 Jyväskylä, Finland; \\ matti.o.haukka@jyu.fi \\ 3 Department of Chemistry, College of Science, King Saud University, P.O. Box 2455, Riyadh 11451, Saudi Arabia; \\ halbahli@ksu.edu.sa \\ 4 Department of Zoology, College of Science, King Saud University, P.O. Box 2455, Riyadh 11451, Saudi Arabia; \\ nabutaha@ksu.edu.sa \\ 5 Department of Chemistry, Faculty of Science, Alexandria University, P.O. Box 426, Ibrahimia, \\ Alexandria 21321, Egypt \\ * Correspondence: jlasri@kau.edu.sa (J.L.); aelfaham@ksu.edu.sa (A.E.-F.); saied1soliman@yahoo.com (S.M.S.)
}

check for updates

Citation: Lasri, J.; Haukka, M.; Al-Rasheed, H.H.; Abutaha, N.; El-Faham, A.; Soliman, S.M. Synthesis, Structure and In Vitro Anticancer Activity of Pd(II) Complex of Pyrazolyl-s-Triazine Ligand; A New Example of Metal-Mediated Hydrolysis of $s$-Triazine Pincer Ligand. Crystals 2021, 11, 119. https://doi.org/10.3390/cryst11020119

Academic Editor: Yulia V. Nelyubina Received: 24 December 2020

Accepted: 23 January 2021

Published: 27 January 2021

Publisher's Note: MDPI stays neutral with regard to jurisdictional claims in published maps and institutional affiliations.

Copyright: (C) 2021 by the authors. Licensee MDPI, Basel, Switzerland. This article is an open access article distributed under the terms and conditions of the Creative Commons Attribution (CC BY) license (https:/ / creativecommons.org/licenses/by/ $4.0 /)$.
Abstract: The square planar complex $\left[\mathrm{Pd}(\mathrm{PT}) \mathrm{Cl}\left(\mathrm{H}_{2} \mathrm{O}\right)\right] * \mathrm{H}_{2} \mathrm{O}$ (HPT: 6-(3,5-dimethyl-1H-pyrazol-1-yl)1,3,5-triazine-2,4(1H,3H)-dione) was obtained by the reaction of 2-methoxy-4,6-bis(3,5-dimethyl- $1 H$ pyrazol-1-yl)-1,3,5-triazine (MBPT) pincer ligand with $\mathrm{PdCl}_{2}$ in a molar ratio (1:1) under thermal conditions and using acetone as a solvent. The reaction proceeded via $\mathrm{C}-\mathrm{N}$ cleavage of one $\mathrm{C}-\mathrm{N}$ moiety that connects the pyrazole and s-triazine combined with the hydrolysis of the $\mathrm{O}-\mathrm{CH}_{3}$ group. The reaction of the chloride salt of its higher congener $\left(\mathrm{PtCl}_{2}\right)$ gave $\left[\mathrm{Pt}(3,5 \text {-dimethyl- } 1 \mathrm{H} \text {-pyrazole })_{2} \mathrm{Cl}_{2}\right]$. The crystal structure of $\left[\mathrm{Pd}(\mathrm{PT}) \mathrm{Cl}\left(\mathrm{H}_{2} \mathrm{O}\right)\right]{ }^{*} \mathrm{H}_{2} \mathrm{O}$ complex is stabilized by inter- and intra-molecular hydrogen bonding interactions. Hirshfeld analysis revealed that the H...H (34.6\%), О...H (23.6\%), and $\mathrm{Cl} \ldots \mathrm{H}(7.8 \%)$ interactions are the major contacts in the crystal. The charges at $\mathrm{Pd}, \mathrm{H}_{2} \mathrm{O}, \mathrm{Cl}$ and PT are changed to $0.4995,0.2216,-0.4294$ and -0.2917 instead of $+2,0,-1$ and -1 , respectively, using the MPW1PW91 method. $\left[\mathrm{Pd}(\mathrm{PT}) \mathrm{Cl}\left(\mathrm{H}_{2} \mathrm{O}\right)\right]^{*} \mathrm{H}_{2} \mathrm{O}$ complex has almost equal activities against MDA-MB-231 and MCF-7 cell lines with $\mathrm{IC}_{50}$ of $38.3 \mu \mathrm{g} / \mathrm{mL}$.

Keywords: Pd(II) complex; pyrazole; s-triazine; hirshfeld; DFT; MCF-7; MDA-MD-231

\section{Introduction}

Palladium(II) compounds have many applications in C-C cross-coupling reactions (e.g. Suzuki-Miyaura, Mizoroki-Heck, etc.) [1-4]. In addition, the combination of heterocyclic ligands with $\mathrm{Pd}$ metal center leads to new active compounds [5], where complexes with Pd(II) metal center are good candidates for discovering new anti-cancer agents [6-15]. Graham et al. [16] reported the use of Pd(II) compounds as plausible anti-cancer agents. Moreover, various $\mathrm{Pd}(\mathrm{II})$ compounds have been synthesized and showed promising anti-cancer activities. In some cases, Pd(II) metal complexes have shown better anti-cancer activity than their Pt(II) analogs [12-15]. In fact, Pd(II) complexes have lately been showed an important anti-tumor activity to cancer cells with minor side effects compared to cisplatin $[15,17]$.

In addition, the s-triazine scaffold is a key for the preparation of various products with important applications in pharmaceutical chemistry [18-22]. In the previous studies by Soliman and El-Faham group, the reactions of 2,4-bis(3,5-dimethyl-1H-pyrazol-1-yl)-6methoxy-1,3,5-triazine (MBPT; Figure 1) pincer ligand with different metal ions such as $\mathrm{Ni}(\mathrm{II}), \mathrm{Co}(\mathrm{II}), \mathrm{Mn}(\mathrm{II}), \mathrm{Cd}(\mathrm{II}), \mathrm{Cu}(\mathrm{II})$ and $\mathrm{Zn}(\mathrm{II})$ were examined [23-31]. For the majority of 
these reactions, the corresponding pincer complexes were obtained with varied coordination numbers depending on the metal ion. It ranges from 5 in the case of $\left[\mathrm{Cd}\left(\mathrm{MBPT} \mathrm{Cl}_{2}\right]\right.$ to 8 for the corresponding nitrato complex, while in the majority of metal ions, the coordination number was 6 . In few cases, the reaction proceeded with the decomposition of the pincer ligand. In the presence of $\mathrm{ZnCl}_{2}$, the C-N cleavage of the MBPT was achieved, and the $\left[\mathrm{Zn}(3,5 \text {-dimethyl-1H-pyrazole })_{2} \mathrm{Cl}_{2}\right]$ was obtained [23]. In another instance, the reactions with $\mathrm{Cu}(\mathrm{II})$ salts yielded $1 \mathrm{D}$ polymeric complexes due to the hydrolysis of the MBPT ligand [25]. In the presence of $\mathrm{Cu}(\mathrm{II})$ perchlorate salt, the hydrolysis occurred only for the methoxy group, while in the case of $\mathrm{CuCl}_{2}$ the hydrolysis occurred at one C-N with the pyrazolyl moiety in addition to the hydrolysis of the methoxy group [25]. In this publication, we tested the reaction of $\mathrm{MCl}_{2}(\mathrm{M}=\mathrm{Pd}$ or Pt) salts with MBPT ligand and the structure of the resulting complexes were established using single-crystal $\mathrm{X}$-ray diffraction. Additionally, the anti-cancer activities of the new $\mathrm{Pd}(\mathrm{II})$ complex were also reported here against breast cancer cell lines (MCF-7 and MDA-MB-231).<smiles>COc1nc(-n2nc(C)cc2C)nc(-n2nc(C)cc2C)n1</smiles>

Figure 1. Structure of the ligand (MBPT).

\section{Materials and Methods}

Solvents and reagents were bought from Sigma-Aldrich Chemie GmbH, 82024 Taufkirchen, Germany. The C, H, and N analyses were determined using Perkin-Elmer 2400 elemental analyzer.

\subsection{Syntheses of Ligand and $\left[\mathrm{Pd}(\mathrm{PT}) \mathrm{Cl}\left(\mathrm{H}_{2} \mathrm{O}\right)\right]^{*} \mathrm{H}_{2} \mathrm{O}$}

\subsubsection{Synthesis of MBPT Ligand}

The ligand MBPT was prepared following the reported method [30,31]. The spectral data agreed with the reported one (see in Supplementary Material, Figure S1).

\subsubsection{Synthesis of $\left[\mathrm{Pd}(\mathrm{PT}) \mathrm{Cl}\left(\mathrm{H}_{2} \mathrm{O}\right)\right]^{*} \mathrm{H}_{2} \mathrm{O}$}

$\mathrm{PdCl}_{2}$ (35.5 mg, $0.200 \mathrm{mmol}$ ) was added to a solution of 2-methoxy-4,6-bis(3,5-dimethyl1H-pyrazol-1-yl)-1,3,5-triazine (MBPT) ligand $(60.0 \mathrm{mg}, 0.200 \mathrm{mmol})$ in acetone $(20 \mathrm{~mL})$. The reaction mixture was stirred for 3 days at $50{ }^{\circ} \mathrm{C}$. After that time, the solution was filtered from the insoluble materials and kept at room temperature for slow evaporation to afford the target crystalline complex $\left[\mathrm{Pd}(\mathrm{PT}) \mathrm{Cl}\left(\mathrm{H}_{2} \mathrm{O}\right)\right]^{*} \mathrm{H}_{2} \mathrm{O}$. Yield: $92 \%$. Anal. Calcd for $\mathrm{C}_{8} \mathrm{H}_{12} \mathrm{ClN}_{5} \mathrm{O}_{4} \mathrm{Pd}: \mathrm{C}, 25.02 ; \mathrm{H}, 3.15 ; \mathrm{N}, 18.23$. Found: C, 24.86; H, 3.04; N, 18.15 .

Following the same procedures, the reaction of $\mathrm{PtCl}_{2}$ with the same ligand afforded the $\left[\mathrm{Pt}(3,5 \text {-dimethyl- } 1 \mathrm{H} \text {-pyrazole })_{2} \mathrm{Cl}_{2}\right]$ complex also indicating the hydrolysis of $\mathbf{M B P T}$. The crystals were isolated and the solid-state structure was established using X-ray diffraction of a single crystal, and it is found to agree with the previously reported structure by Khripun et al. [32].

\subsection{Crystal Structure Determination}

The crystal of $\left[\mathrm{Pd}(\mathrm{PT}) \mathrm{Cl}\left(\mathrm{H}_{2} \mathrm{O}\right)\right]^{*} \mathrm{H}_{2} \mathrm{O}$ was immersed in cryo-oil, mounted in a loop, and measured at a temperature of $170 \mathrm{~K}$. The X-ray diffraction data was collected on a Bruker Kappa Apex II diffractometer using MoK $\alpha$ radiation. The Denzo-Scalepack [33] software package was used for cell refinement and data reduction. A numerical absorption correction 
(SADABS [34]) was applied to the intensities before structure solution. The structure was solved by the intrinsic phasing method using the SHELXT [35] software. Structural refinement was carried out using SHELXL [36] software. The $\mathrm{H}_{2} \mathrm{O}$ and $\mathrm{NH}$ hydrogen atoms were located from the difference Fourier map and refined isotropically. Other hydrogen atoms were positioned geometrically and constrained to ride on their parent atoms, with $\mathrm{C}-\mathrm{H}=0.95-0.98 \AA$ and $\mathrm{U}_{\mathrm{iso}}=1.2-1.5 \mathrm{U}_{\text {eq }}$ (parent atom). The crystallographic details are summarized in Table 1 .

Table 1. Crystal data and structure refinement for $\left[\mathrm{Pd}(\mathrm{PT}) \mathrm{Cl}\left(\mathrm{H}_{2} \mathrm{O}\right)\right]^{*} \mathrm{H}_{2} \mathrm{O}$.

\begin{tabular}{|c|c|}
\hline Empirical Formula & $\mathrm{C}_{8} \mathrm{H}_{12} \mathrm{ClN}_{5} \mathrm{O}_{4} \mathrm{Pd}$ \\
\hline Formula weight & 384.08 \\
\hline Temperature & $170(2) \mathrm{K}$ \\
\hline Wavelength & $0.71073 \AA$ \\
\hline Crystal system & Monoclinic \\
\hline Space group & $C 2 / c$ \\
\hline Unit cell dimensions & $a=20.3494(9) \AA$ \\
\hline & $\mathrm{b}=7.1687(2) \AA$ \\
\hline & $c=19.9275(8) \AA$ \\
\hline Volume & 2517.43(17) А̊3 \\
\hline $\mathrm{Z}$ & 8 \\
\hline Density (calculated) & $2.027 \mathrm{Mg} / \mathrm{m}^{3}$ \\
\hline Absorption coefficient & $1.705 \mathrm{~mm}^{-1}$ \\
\hline $\mathrm{F}(000)$ & 1520 \\
\hline Crystal size & $0.372 \times 0.171 \times 0.153 \mathrm{~mm}^{3}$ \\
\hline Theta range for data collection & 3.501 to $27.482^{\circ}$ \\
\hline Index ranges & $-19 \leq \mathrm{h} \leq 26,-9 \leq \mathrm{k} \leq 9,-25 \leq 1 \leq 25$ \\
\hline Reflections collected & 11,575 \\
\hline Independent reflections & $2843[\mathrm{R}(\mathrm{int})=0.0253]$ \\
\hline Completeness to theta $=25.242^{\circ}$ & $98.3 \%$ \\
\hline Absorption correction & Numerical \\
\hline Max. and min. transmission & 0.7994 and 0.6924 \\
\hline Refinement method & Full-matrix least-squares on $\mathrm{F}^{2}$ \\
\hline Data / restraints / parameters & $2843 / 0 / 194$ \\
\hline Goodness-of-fit on F2 & 1.091 \\
\hline Final $R$ indices $[\mathrm{I}>2 \operatorname{sigma}(\mathrm{I})]$ & $\mathrm{R} 1=0.0230, \mathrm{wR} 2=0.0510$ \\
\hline $\mathrm{R}$ indices (all data) & $\mathrm{R} 1=0.0268, \mathrm{wR} 2=0.0529$ \\
\hline Largest diff. peak and hole & 0.477 and -0.460 e $\AA^{-3}$ \\
\hline CCDC & 2048907 \\
\hline
\end{tabular}

\subsection{Hirshfeld Analysis}

Hirshfeld surfaces were computed using Crystal Explorer 17.5 program [37].

\subsection{Computational Details}

Gaussian 09 program [38] was used for DFT calculations. MPW1PW91 and $\omega$ B97XD methods [39,40] combined with cc-PVTZ and cc-PVTZ-PP [41-43] as basis sets for nonmetal atoms and $\mathrm{Pd}$, respectively, were used for natural charge populations [44] at the X-ray structure coordinates of the studied $\mathrm{Pd}(\mathrm{II})$ complex.

\subsection{In Vitro Anti-Cancer Activity}

In vitro anti-cancer activities against two breast adenocarcinoma (MDA-MB-231 and MCF-7) cell lines were tested (see in Supplementary Material, Method S1).

\subsubsection{Cell Culture Conditions}

Breast cancer cell lines MDA-MB-231 and MCF-7 were obtained from the German Type Cell Culture Collection (DSMZ, Germany). Cells were maintained in high glu- 
cose Dulbecco's Modified Eagle Medium supplemented with $10 \%$ of fetal bovine serum (Gibco, USA).

\subsubsection{MTT Assay}

3-(4,5-Dimethylthiazol-2-yl)-2,5-diphenyltetrazolium bromide (MTT) assay was carried out according to the previous report by Abutaha et al. [45]. Briefly, trypsin was added to MDA-MB-231, and MCF-7 cells, and then cells were counted and seeded at $5 \times 10^{4}$ cells/well in the 24 -well plate for $24 \mathrm{~h}$. The following day, cells were incubated with different concentrations of the compounds for $48 \mathrm{~h}$ with $5 \% \mathrm{CO}_{2}$ at $37^{\circ} \mathrm{C}$. After that, $100 \mu \mathrm{L}$ of MTT $(5 \mathrm{mg} / \mathrm{mL}$ ) (Thermo, USA) was added to each well and left for $2 \mathrm{~h}$. Next, the supernatant was discarded, and $1000 \mu \mathrm{L}$ of methanol was added, and the formazan was quantified at $595 \mathrm{~nm}$ using a microplate reader. Triplicates were used to calculate the cell viability percentage and the $\mathrm{IC}_{50}$ values using OriginPro 8.5 software.

\section{Results and Discussion}

\subsection{X-ray Structure Description of $\left[\mathrm{Pd}(\mathrm{PT}) \mathrm{Cl}\left(\mathrm{H}_{2} \mathrm{O}\right)\right]^{*} \mathrm{H}_{2} \mathrm{O}$}

In $\left[\mathrm{Pd}(\mathrm{PT}) \mathrm{Cl}\left(\mathrm{H}_{2} \mathrm{O}\right)\right]^{*} \mathrm{H}_{2} \mathrm{O}$ complex, the $\mathrm{Pd}(\mathrm{II})$ is coordinated by a chloride anion, one water molecule as monodentate ligands and two nitrogen atoms from the chelating ligand $\mathbf{P T}^{-1}$ as a mononegative bidentate $N N$-chelate. The $\mathrm{Pd}(\mathrm{II})$ exhibiting slightly distorted square planar coordination geometry (Table 2, Figure 2). The structure of the metal complex is supported by one intramolecular H-bond between the coordinated water molecule (H1A) and the oxygen $(\mathrm{O} 2)$, forming the organic chelate $\left(\mathbf{P T}^{-\mathbf{1}}\right)$, leading to the six-membered ring (Figure 3). The asymmetric unit also contains water of crystallization. The $\mathrm{NH}_{2}$-group and the oxygen $\mathrm{O} 3$ are involved in a pair of hydrogen bonds binding the metal complex with the adjacent molecule at the equivalent position of $-x+1, y,-z+1.5$. The aqua ligand is also hydrogen bonded to the water of crystallization (Figure 3). The water of crystallization forms additional hydrogen bonds with chloride ligand as well as with O6 of the neighboring metal complexes. Additional weak $\mathrm{CH} \cdots \mathrm{O}$ type $\mathrm{H}$-bonds (C6-H6 $\cdots \mathrm{O} 4$ and $\mathrm{C} 8-\mathrm{H} 8 \mathrm{C} \cdots \mathrm{O} 4)$ are supporting the overall packing of the molecules. The hydrogen bonds are summarized in Table 3 and Figure 3. Packing of the Pd(II) complex units stacked along the crystallographic $b$-axis is shown in Figure 4 .
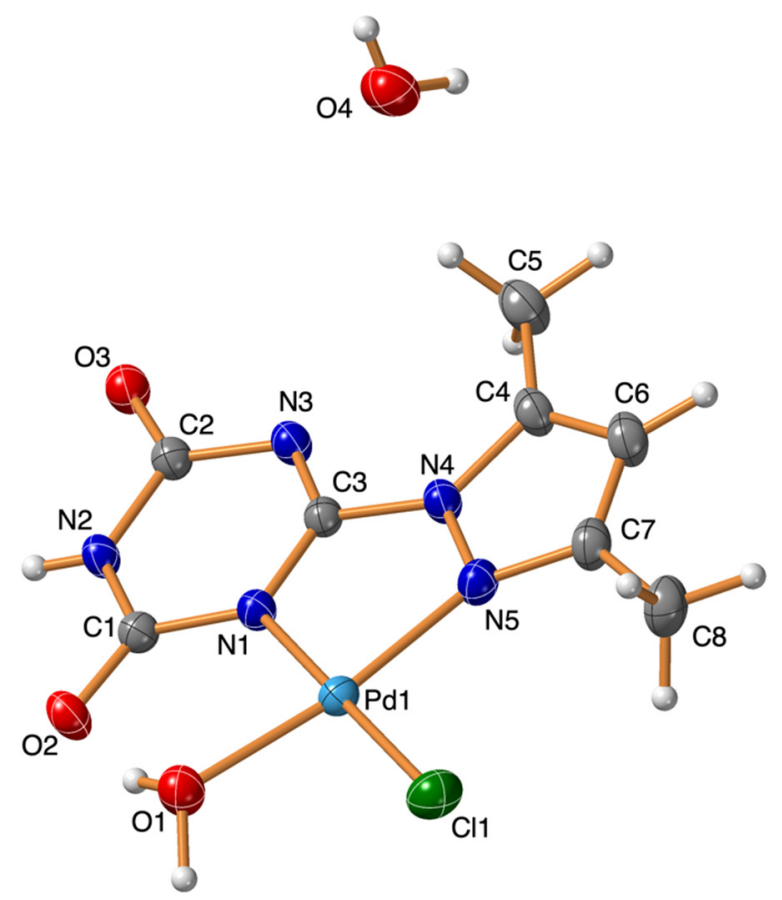

Figure 2. Thermal ellipsoids plots of $\left[\mathrm{Pd}(\mathrm{PT}) \mathrm{Cl}\left(\mathrm{H}_{2} \mathrm{O}\right)\right]^{*} \mathrm{H}_{2} \mathrm{O}$. Thermal ellipsoids are drawn at the $50 \%$ probability level. 


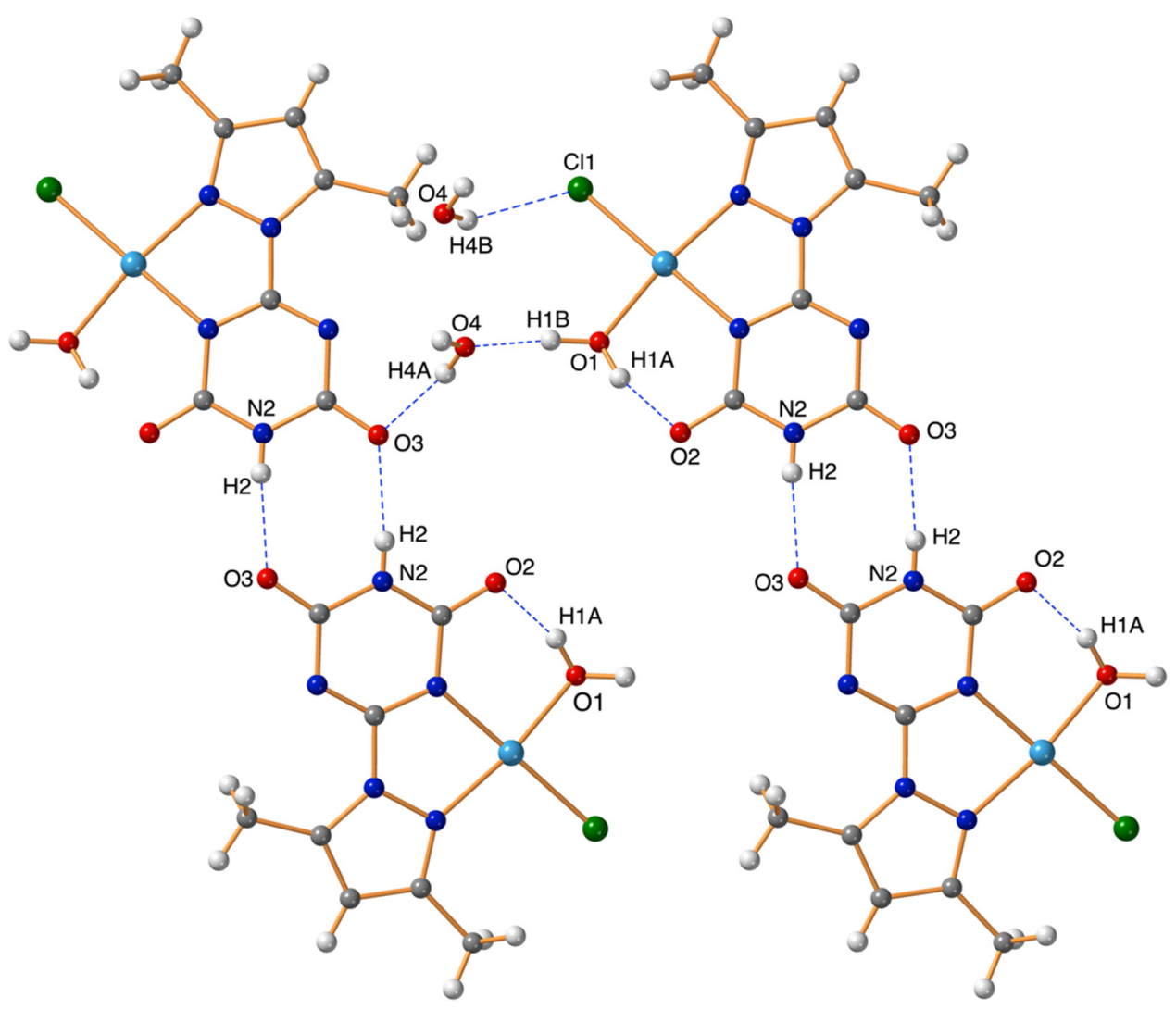

Figure 3. Part of $\mathrm{H}$-bonding network in $\left[\mathrm{Pd}(\mathrm{PT}) \mathrm{Cl}\left(\mathrm{H}_{2} \mathrm{O}\right)\right]^{*} \mathrm{H}_{2} \mathrm{O}$.

Table 2. Selected bond lengths $[\AA]$ and angles $\left[{ }^{\circ}\right]$ for $\left[\mathrm{Pd}(\mathrm{PT}) \mathrm{Cl}\left(\mathrm{H}_{2} \mathrm{O}\right)\right]^{*} \mathrm{H}_{2} \mathrm{O}$.

\begin{tabular}{cc}
\hline $\mathbf{P d}(\mathbf{1})-\mathbf{N}(\mathbf{5})$ & $\mathbf{1 . 9 9 5 3 ( 1 9 )}$ \\
\hline $\operatorname{Pd}(1)-\mathrm{N}(1)$ & $2.0141(18)$ \\
$\operatorname{Pd}(1)-\mathrm{O}(1)$ & $2.0155(17)$ \\
$\operatorname{Pd}(1)-\mathrm{Cl}(1)$ & $2.2838(6)$ \\
$\mathrm{N}(5)-\mathrm{Pd}(1)-\mathrm{N}(1)$ & $79.93(7)$ \\
$\mathrm{N}(5)-\mathrm{Pd}(1)-\mathrm{O}(1)$ & $171.77(8)$ \\
$\mathrm{N}(1)-\mathrm{Pd}(1)-\mathrm{O}(1)$ & $93.50(8)$ \\
$\mathrm{N}(5)-\operatorname{Pd}(1)-\mathrm{Cl}(1)$ & $99.55(6)$ \\
$\mathrm{N}(1)-\mathrm{Pd}(1)-\mathrm{Cl}(1)$ & $179.10(6)$ \\
$\mathrm{O}(1)-\operatorname{Pd}(1)-\mathrm{Cl}(1)$ & $87.08(6)$ \\
\hline
\end{tabular}

Table 3. Hydrogen bonds for $\left[\mathrm{Pd}(\mathrm{PT}) \mathrm{Cl}\left(\mathrm{H}_{2} \mathrm{O}\right)\right]^{*} \mathrm{H}_{2} \mathrm{O}\left[\AA\right.$ and $\left.{ }^{\circ}\right]$.

\begin{tabular}{ccccc}
\hline $\mathbf{D}-\mathbf{H} \cdots \mathbf{A}$ & $\mathbf{d}(\mathbf{D}-\mathbf{H})$ & $\mathbf{d}(\mathbf{H} \cdots \mathbf{A})$ & $\mathbf{d}(\mathbf{D} \cdots \mathbf{A})$ & $<$ (DHA) \\
\hline $\mathrm{C}(6)-\mathrm{H}(6) \ldots \mathrm{O}(2) \# 1$ & 0.95 & 2.49 & $3.406(3)$ & 161.5 \\
$\mathrm{O}(4)-\mathrm{H}(4 \mathrm{~A}) \ldots \mathrm{O}(3) \# 2$ & $0.88(4)$ & $1.98(4)$ & $2.821(3)$ & $161(3)$ \\
$\mathrm{O}(1)-\mathrm{H}(1 \mathrm{~A}) \ldots \mathrm{O}(2)$ & $0.92(4)$ & $1.69(4)$ & $2.587(3)$ & $161(4)$ \\
$\mathrm{O}(4)-\mathrm{H}(4 \mathrm{~B}) \ldots \mathrm{Cl}(1) \# 3$ & $0.75(4)$ & $2.61(4)$ & $3.278(2)$ & $148(4)$ \\
$\mathrm{O}(4)-\mathrm{H}(4 \mathrm{~B}) \ldots \mathrm{O}(4) \# 4$ & $0.75(4)$ & $2.59(4)$ & $2.986(5)$ & $115(3)$ \\
$\mathrm{O}(1)-\mathrm{H}(1 \mathrm{~B}) \ldots \mathrm{O}(4) \# 5$ & $0.97(4)$ & $1.65(4)$ & $2.592(3)$ & $163(4)$ \\
$\mathrm{N}(2)-\mathrm{H}(2) \ldots \mathrm{O}(3) \# 6$ & $0.78(3)$ & $2.07(3)$ & $2.840(3)$ & $172(3)$ \\
$\mathrm{C}(6)-\mathrm{H}(6) \ldots \mathrm{O}(2) \# 1$ & 0.95 & 2.49 & $3.406(3)$ & 161.5 \\
$\mathrm{C}(8)-\mathrm{H}(8 \mathrm{C}) \ldots \mathrm{O}(4) \# 7$ & 0.98 & 2.71 & $3.629(3)$ & 155.9 \\
$\mathrm{O}(4)-\mathrm{H}(4 \mathrm{~B}) \ldots \mathrm{Cl}(1) \# 3$ & $0.75(4)$ & $2.61(4)$ & $3.278(2)$ & $148(4)$ \\
\hline
\end{tabular}

Symmetry transform: \#1 $x,-y+1, z-1 / 2 \# 2-x+1,-y+1,-z+1 \# 3 x+1 / 2, y-1 / 2, z \# 4-x+1,-y,-z+1$ $\# 5-x+1 / 2,-y+1 / 2,-z+1 \# 6-x+1, y,-z+3 / 2$ \# $-x+1 / 2, y+1 / 2,-z+1 / 2$. 


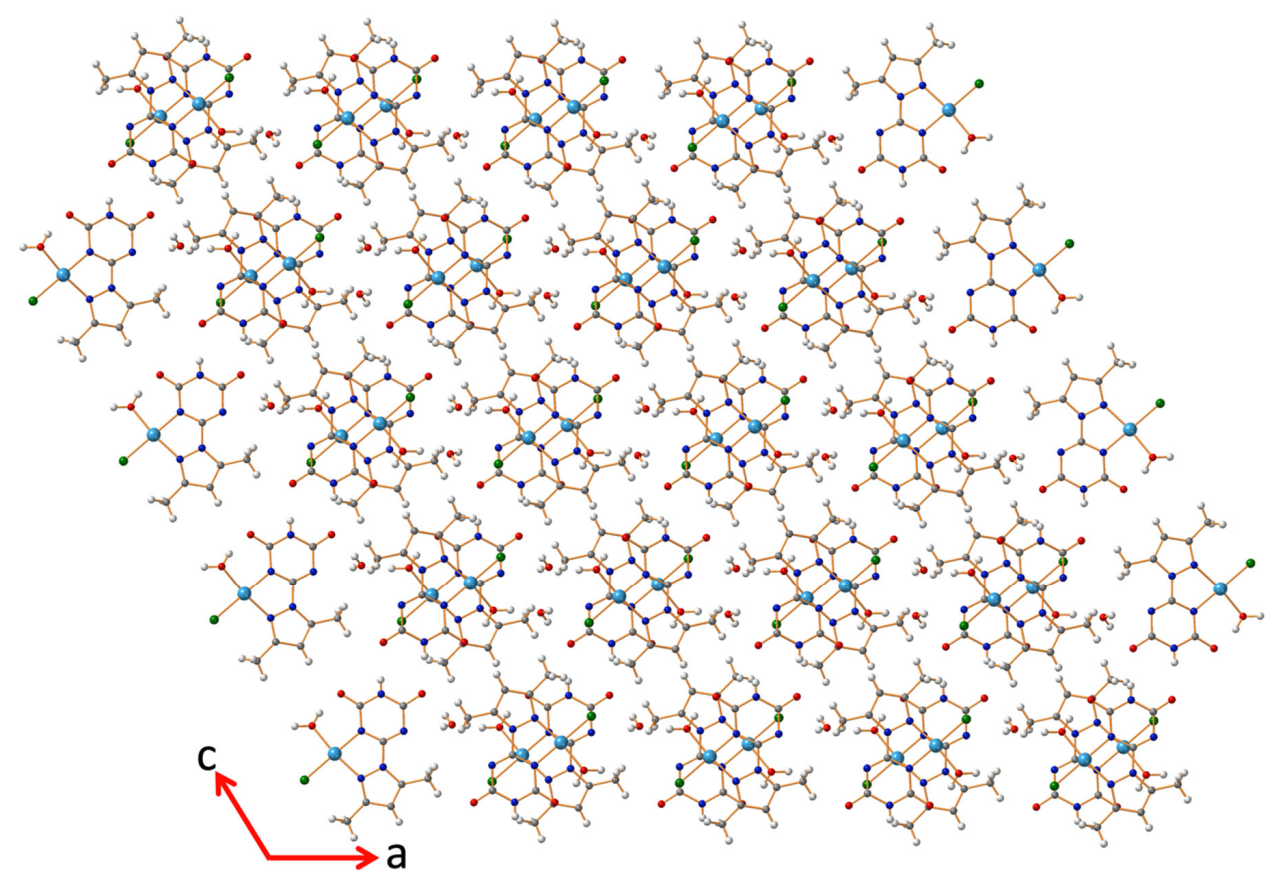

Figure 4. Packing of $\left[\mathrm{Pd}(\mathrm{PT}) \mathrm{Cl}\left(\mathrm{H}_{2} \mathrm{O}\right)\right]^{*} \mathrm{H}_{2} \mathrm{O}$ along crystallographic $b$-axis.

\subsection{Hirshfeld Analysis of Molecular Packing}

Hirshfeld surfaces mapped over $d_{\text {norm }}$, shape index (SI) and curvedness for the studied complex are shown in Figure S2 (see in Supplementary Material). Quantitative analysis of molecular packing is given in Figure 5. The $\mathrm{H} \ldots \mathrm{H}(34.6 \%), \mathrm{O} \ldots \mathrm{H}(23.6 \%)$, and $\mathrm{Cl} \ldots \mathrm{H}(7.8 \%)$ interactions are the major contacts in the crystal. For this complex, the N2$\mathrm{H} 2 \ldots \mathrm{O} 3, \mathrm{O} 4-\mathrm{H} 4 \mathrm{~A} \ldots \mathrm{OO} 3, \mathrm{O} 1-\mathrm{H} 1 \mathrm{~B} \ldots \mathrm{O} 4$ and $\mathrm{C} 6-\mathrm{H} 6 . . . \mathrm{O} 2$ hydrogen bonds were observed at hydrogen-acceptor distances of $1.838,1.876,1.636$, and $2.366 \AA$, respectively using Hirshfeld calculations. The first three hydrogen bonding interactions appeared as intense red spots indicating that these interactions are the most significant, while the $\mathrm{C}-\mathrm{H}$...O hydrogen bond is less important (Figure 6). The $\mathrm{N}-\mathrm{H} . . . \mathrm{O}$ and $\mathrm{O}-\mathrm{H} . . . \mathrm{O}$ hydrogen bonds appeared as sharp spikes in the fingerprint plot. Another intense red spot was observed close to the coordinated chloride ion corresponding to the O4-H4B...Cl1 with $\mathrm{H} . . . \mathrm{Cl}$ contact distance of $2.415 \AA$ and one sharp spike in the fingerprint plot indicating that the chloride ion inside the surface acting as hydrogen bond acceptor. In addition, every two complex units forming a dimer via two equivalent C1...N5 contacts ( $3.344 \AA$ ) along the crystallographic $b$-direction indicating weak $\pi-\pi$ stacking interactions, which is further indicated by the presence of blue/red triangle in the shape index map.

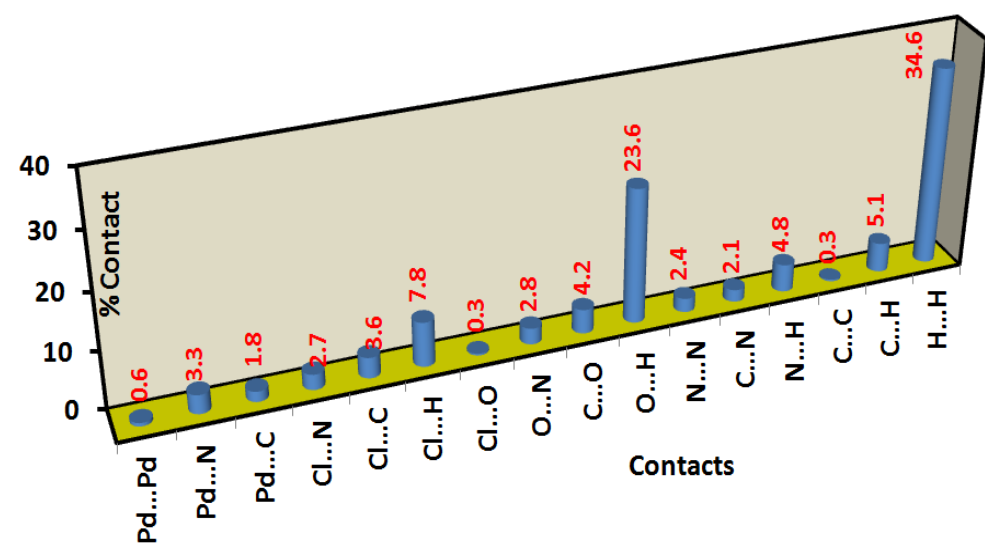

Figure 5. All possible intermolecular interactions and their percentages in the $\mathrm{Pd}(\mathrm{II})$ complex. 


\section{(I): $\mathrm{O} . . . \mathrm{H}$ contacts}
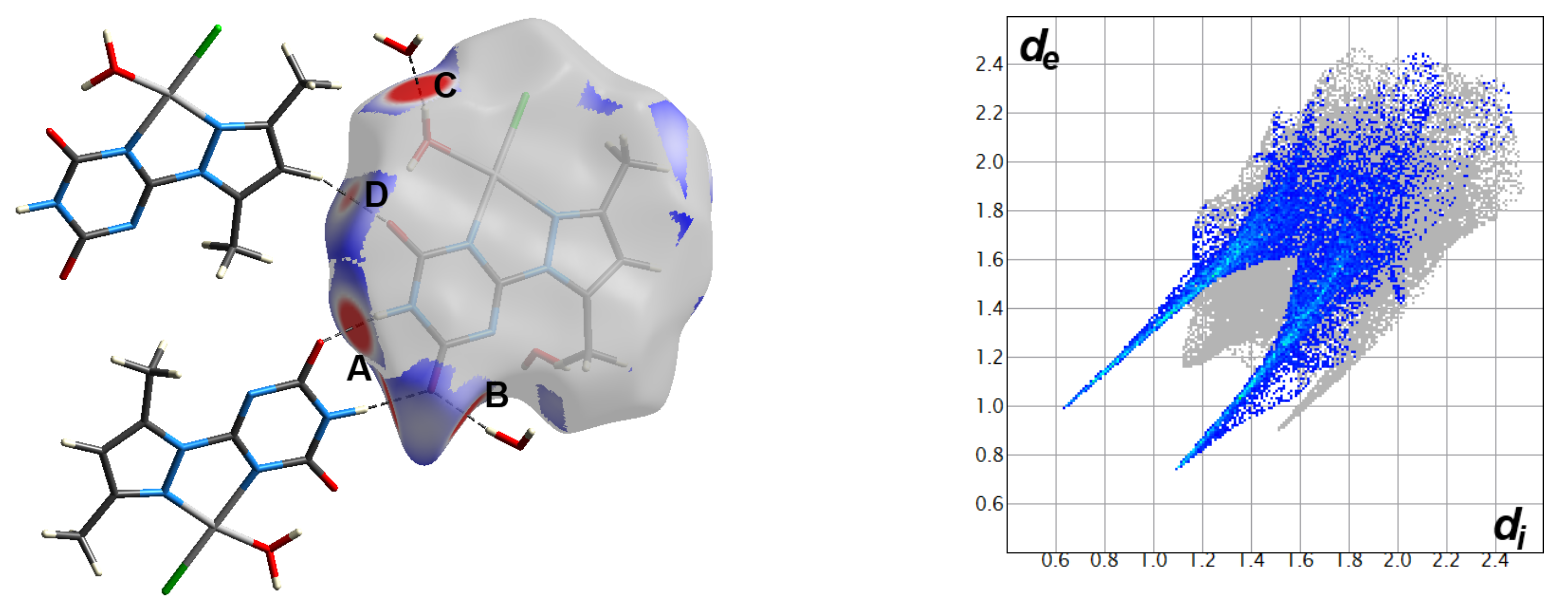

(II): $\mathrm{Cl}$...H contacts
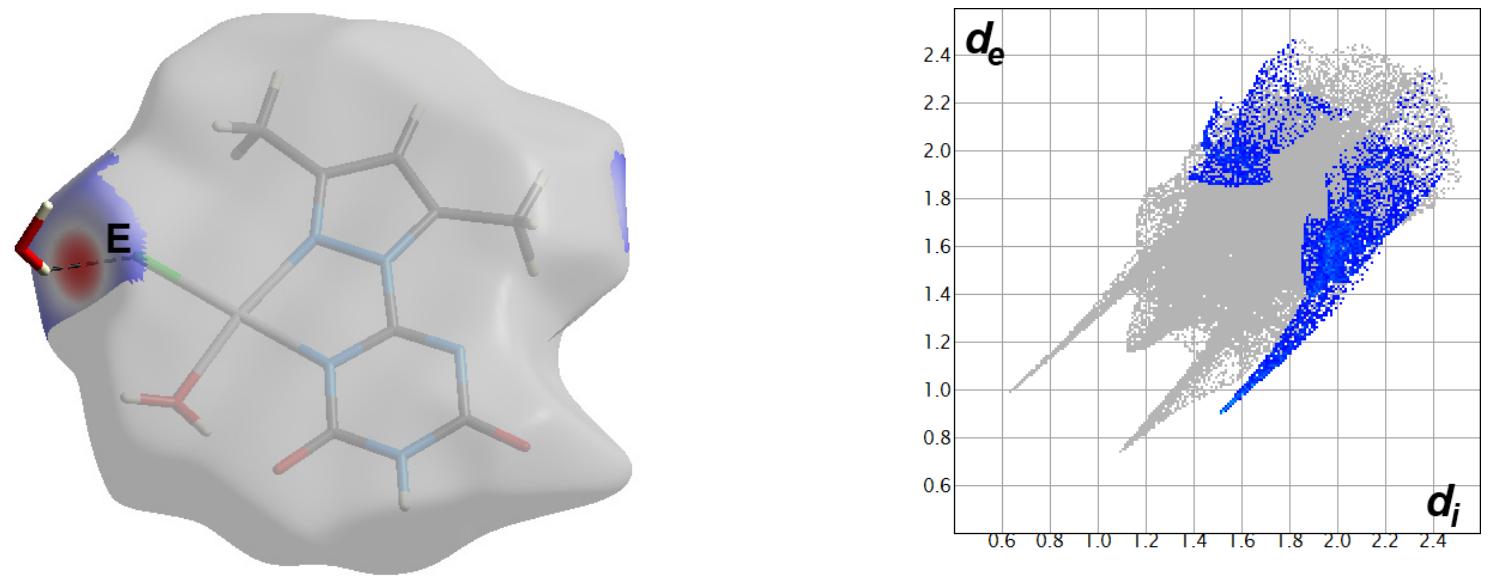

(III): $\pi-\pi$ stacking interactions
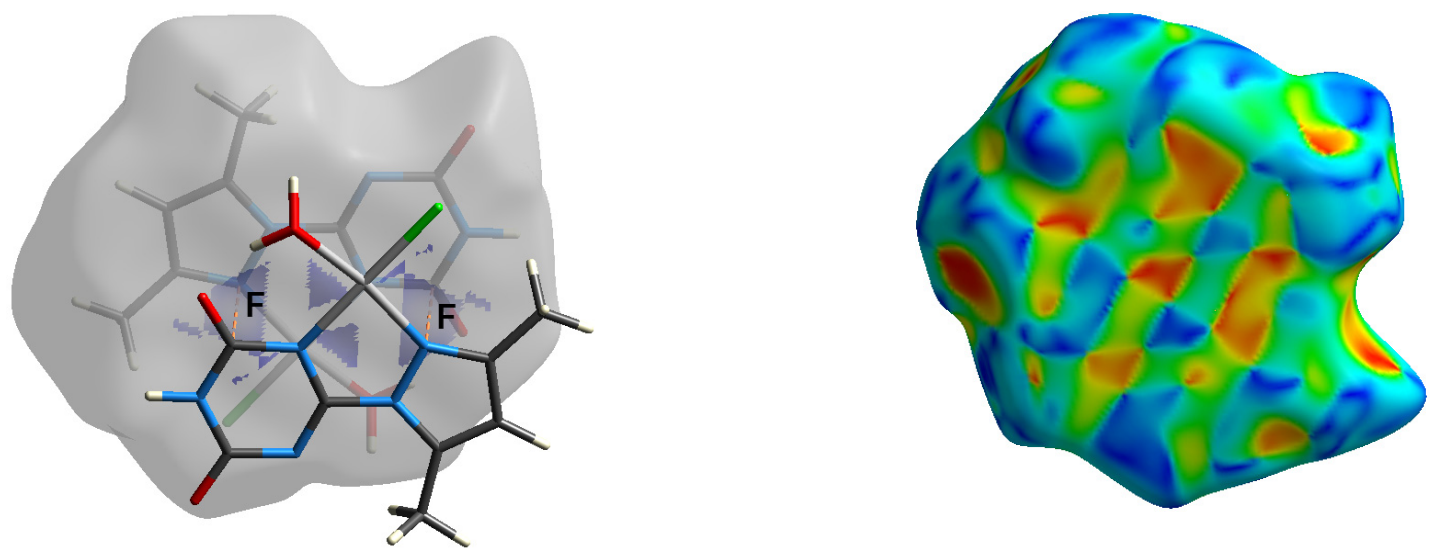

Shape index

Figure 6. The Hirshfeld analysis of (I): $\mathrm{O} \ldots \mathrm{H}$; (II): $\mathrm{Cl} \ldots \mathrm{H}$ and (III): $\pi-\pi$ stacking interactions. The most important interactions are $\mathrm{N} 2-\mathrm{H} 2 \ldots \mathrm{O} 3$ (A), O4-H4A...O3 (B), O1-H1B...O4 (C), C6-H6...O2 (D) and O4-H4B...Cl1 (E) hydrogen bonds, as well as weak $\pi-\pi$ stacking interactions via long C1...N5 (F) contacts. 


\subsection{Natural Population Analysis}

The divalent Pd ion is coordinated with two negatively charged ligand groups, which are $\mathrm{Cl}^{-}$and $\mathbf{P T}^{-}$. These isolated ions have a net charge of $-1 \mathrm{e}$. As a result of the interactions between the $\mathrm{Pd}(\mathrm{II})$ ion as Lewis acid and these ligand groups as Lewis base, there are some electrons that are transferred from the ligand groups to Pd(II) ion (Table 4). Two DFT methods (MPW1PW91 and $\omega$ B97XD) employing natural charge population analysis [46] which has low sensitivity to the basis set variations, were used for this task. The chloride ion transferred $0.571-0.527$ e to the $\mathrm{Pd}(\mathrm{II})$ while the anionic organic ligand $\left(\mathbf{P T}^{-}\right)$as a bidentate chelate transferred a large amount (0.708-0.701 e) of its negative charge to the metal center while the coordinated water molecule has a net charge of $0.2216-0.2172$ e. As a result, the water molecule as ligand transferred about $0.2 \mathrm{e}$ to $\mathrm{Pd}(\mathrm{II})$. The net charge of Pd was decreased to $0.500-0.527$ e. Since the charges transferred are not associated with a physical observable [47], one could conclude that there are some charges that are transferred from the ligand groups to the $\mathrm{Pd}(\mathrm{II})$ central metal ion, which confirm the coordination between the $\operatorname{Pd}(\mathrm{II})$ and ligand groups.

Table 4. The natural charges at the Pd, coordinated chloride and organic ligands.

\begin{tabular}{ccc}
\hline Atom & MPW1PW91 & WB97XD \\
\hline $\mathrm{Pd}$ & 0.4995 & 0.5273 \\
$\mathrm{H}_{2} \mathrm{O}$ & 0.2216 & 0.2172 \\
$\mathrm{Cl}$ & -0.4294 & -0.4452 \\
$\mathrm{PT}$ & -0.2917 & -0.2992 \\
\hline
\end{tabular}

Another interesting feature that could be discussed is the HOMO and LUMO patterns of the studied system (Figure 7). The energies of these frontier molecular orbitals were calculated to be -7.146 and $-2.358 \mathrm{eV}$, respectively, and the HOMO-LUMO transition required an energy of $4.789 \mathrm{eV}$ using the MPW1PW91 method. As can be seen from Figure 7, the HOMO is mainly localized over the $\mathrm{Pd}(\mathrm{II})$, which has a major contribution from the $\mathrm{dz}^{2}$ orbital, while the LUMO is distributed over the metal and organic ligand skeleton, suggesting $\mathrm{d}$-d transition mixed with metal-ligand charge transfer transitions.

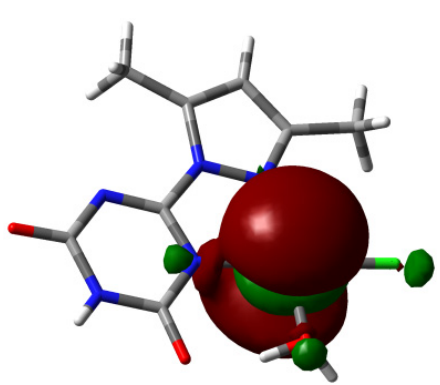

(a)

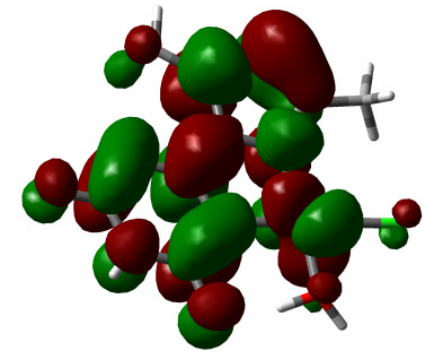

(b)

Figure 7. The HOMO (a) and LUMO (b) levels of the studied complex using MPW1PW91 method.

\subsection{In Vitro Anti-Cancer Activity}

Presently, palladium-based drugs are among the most studied drugs in oncology and are attractive substitute metal-based drugs because of considerable similarities to platinum agents regarding structure and coordination chemistry [48]. Palladium-based drugs are known to be active against a wide range of cancer cells with different $\mathrm{IC}_{50}$ values, including MDA-MB-231 ([Pd(sperH) $\left.)_{2}\right]\left[\mathrm{PdCl}_{4}\right]$; sperH: spermidine), HCT 116 ([BzBimy) $\left.{ }_{2} \mathrm{PdCl}_{2}\right]$; BzBimy:1-benzyl-3-tertbutylimidazol-2-ylidene), U-251 Glio ([Pd( $\left.(\mathrm{L}) \mathrm{Cl}_{2}\right]_{2} ; \mathrm{L}$ : (S)-(1phenylethylimino)benzyl phenyl ketone), A549 ([Pd( $\left.\mathrm{dmnP}_{2} \mathrm{Cl}_{2}\right]$; dmnp: 2,6-dimethyl-4nitro-pyridine), $\mathrm{K} 562$ (trans- $\left.\mathrm{PdCl}_{2}[(\mathrm{R})(-) \text { bornylamino }]_{2}\right)$, and many more [49]. In addition, 
$\mathrm{Pd}(\mathrm{II})$ complexes were reported to have more activity against cancer cell lines with less side effects compared to cisplatin $[15,17]$. The studied $\left[\mathrm{Pd}(\mathrm{PT}) \mathrm{Cl}\left(\mathrm{H}_{2} \mathrm{O}\right)\right]^{*} \mathrm{H}_{2} \mathrm{O}$ complex showed a cell growth reduction against both of the tested breast cell lines compared with the control that was inactive at all the tested concentrations. In addition, the complex showed good activity against MDA-MB-231 and MCF-7 cells with same $\mathrm{IC}_{50}$ of $38.3 \mu \mathrm{g} / \mathrm{mL}$ for both cells (Figure 8). This data is somewhat better than the reported data for cisplatin and the $\mathrm{Pd}$ (II) complex of 2-(1-methyl-5-nitroimidazol-2-yl)ethanol after $48 \mathrm{~h}$ of incubation (IC 50 values were 93.0, 42.5 $\mu \mathrm{M}$ for MCF-7 and 87.0 and 39.2 $\mu \mathrm{M}$ for MDA-MB-231 cells, respectively) [50], therefore, this $\left[\mathrm{Pd}(\mathrm{PT}) \mathrm{Cl}\left(\mathrm{H}_{2} \mathrm{O}\right)\right]{ }^{*} \mathrm{H}_{2} \mathrm{O}$ complex showed a promising anti-cancer activity against both tested cell lines.

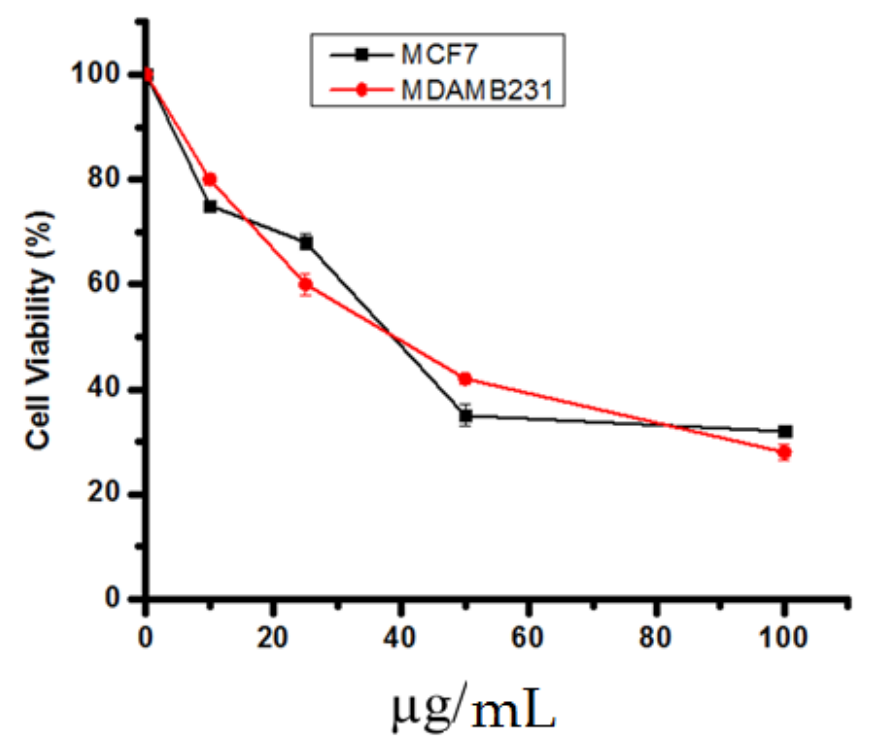

Figure 8. Effect of the concentration of $\left[\mathrm{Pd}(\mathrm{PT}) \mathrm{Cl}\left(\mathrm{H}_{2} \mathrm{O}\right)\right]^{*} \mathrm{H}_{2} \mathrm{O}$ complex on the cell viability against MDA-MB-231 and MCF-7 after $48 \mathrm{~h}$ of treatment. Data are mean \pm standard deviation.

\section{Conclusions}

Under thermal conditions, the reaction of 2-methoxy-4,6-bis(3,5-dimethyl-1H-pyrazol1-yl)-1,3,5-triazine (MBPT) with $\mathrm{PdCl}_{2}$ or $\mathrm{PtCl}_{2}$ afforded $\left[\mathrm{Pd}(\mathrm{PT}) \mathrm{Cl}\left(\mathrm{H}_{2} \mathrm{O}\right)\right]^{*} \mathrm{H}_{2} \mathrm{O}$, or $[\mathrm{Pt}(3,5-$ dimethyl-1H-pyrazole) ${ }_{2} \mathrm{Cl}_{2}$ ], respectively. In the case of $\mathrm{PdCl}_{2}$, partial hydrolysis of MBPT for one pyrazole moiety and the methoxy group was observed. The molecular and supramolecular structural aspects of $\left[\mathrm{Pd}(\mathrm{PT}) \mathrm{Cl}\left(\mathrm{H}_{2} \mathrm{O}\right)\right]^{*} \mathrm{H}_{2} \mathrm{O}$ were examined using $X$-ray single crystallography combined with Hirshfeld and DFT calculations. The stability of the solid-state crystalline $\left[\mathrm{Pd}(\mathrm{PT}) \mathrm{Cl}\left(\mathrm{H}_{2} \mathrm{O}\right)\right]^{*} \mathrm{H}_{2} \mathrm{O}$ complex is mainly controlled by the $\mathrm{H} . . . \mathrm{H}(34.6 \%), \mathrm{O} . . . \mathrm{H}(23.6 \%)$, and $\mathrm{Cl} . . . \mathrm{H}(7.8 \%)$ interactions based on Hirshfeld analysis. Based on natural population analysis, one could speculate that, some amount of negative charge densities were transferred from the ligand groups to $\operatorname{Pd}(\mathrm{II})$ due to the Lewis acid-base interactions. On the other hand, the $\left[\mathrm{Pd}(\mathrm{PT}) \mathrm{Cl}\left(\mathrm{H}_{2} \mathrm{O}\right)\right]^{*} \mathrm{H}_{2} \mathrm{O}$ complex showed a promising activity with $\mathrm{IC}_{50}(38.3 \mu \mathrm{g} / \mathrm{mL})$ against the two tested breast cancer cell lines (MDA-MB-231 and MCF-7).

Supplementary Materials: The following are available online at https:/ / www.mdpi.com/2073-435 2/11/2/119/s1, Method S1 (In vitro anti-cancer experimental details); Figure S1 ( ${ }^{1} \mathrm{H}-$ and ${ }^{13} \mathrm{C}-\mathrm{NMR}$ spectra of the ligand MBPT); Figure S2 (Hirshfeld surfaces of the studied complex).

Author Contributions: H.H.A.-R., N.A., and A.E.-F. carried out the preparation of the organic ligand, analysis, and the biological evaluation. X-ray structure analyses were performed by M.H. and S.M.S. The computational studies and Hirshfeld calculations were carried out by S.M.S. J.L. synthesized the studied complex. All authors contributed to the first draft and the final version. All authors have read and agreed to the published version of the manuscript. 
Funding: Deanship of Scientific Research at King Saud University research group no. (RG-1441-365, Saudi Arabia).

Acknowledgments: The authors extend their thanks to the Deanship of Scientific Research at King Saud University for funding this work through research group no. (RG-1441-365, Saudi Arabia).

Conflicts of Interest: The authors declare no conflict of interest.

\section{References}

1. Lasri, J.; da Silva, M.F.C.G.; Kopylovich, M.N.; Mukhopadhyay, S.; Januário Charmier, M.A.; Pombeiro, A.J.L. Pd ${ }^{\mathrm{II}}$-promoted $[2+3]$ cycloaddition of pyrroline $N$-oxide to organonitriles. Application of $\left(\Delta^{4}-1,2,4\right.$-oxadiazoline)-Pd ${ }^{\mathrm{II}}$ complexes in the Suzuki-Miyaura reaction. Dalton Trans. 2009. [CrossRef] [PubMed]

2. Kopylovich, M.N.; Lasri, J.; da Silva, M.F.C.G.; Pombeiro, A.J.L. Single-pot template transformations of cyanopyridines on a Pd ${ }^{\mathrm{II}}$ centre: Syntheses of ketoimine and 2,4-dipyridyl-1,3,5-triazapentadiene palladium(II) complexes and their catalytic activity for microwave-assisted Suzuki-Miyaura and Heck reactions. Dalton Trans. 2009. [CrossRef] [PubMed]

3. Lasri, J.; Mac Leod, T.C.O.; Pombeiro, A.J.L. Oxadiazoline and ketoimine palladium(II) complexes supported on a chitosan membrane and their catalytic activity for the microwave-assisted Suzuki-Miyaura cross-coupling in water. Appl. Catal. A Gen. 2011, 397, 94-102. [CrossRef]

4. Fernandes, R.R.; Lasri, J.; da Silva, M.F.C.G.; Palavra, A.M.F.; da Silva, J.A.L.; da Silva, J.J.R.F.; Pombeiro, A.J.L. Oxadiazoline and ketoimine palladium(II) complexes as highly efficient catalysts for Suzuki-Miyaura cross-coupling reactions in supercritical carbon dioxide. Adv. Synth. Catal. 2011, 353, 1153-1160. [CrossRef]

5. Lasri, J.; Kopylovich, M.N.; da Silva, M.F.C.G.; Charmier, M.A.J.; Pombeiro, A.J.L. Metal-free and Pd ${ }^{\mathrm{II}}$-promoted [2+3] cycloadditions of a cyclic nitrone to phthalonitriles: Syntheses of oxadiazolines as well as phthalamide-PdII and dihydropyrrolyliminoisoindolinone-Pd ${ }^{\mathrm{II}}$ complexes with high catalytic activity in Suzuki-Miyaura cross-coupling reactions. Chem. Eur. J. 2008, 14, 9312-9322. [PubMed]

6. Kapdi, A.R.; Fairlamb, I.J.S. Anti-cancer palladium complexes: A focus on $\mathrm{PdX}_{2} \mathrm{~L}_{2}$, palladacycles and related complexes. Chem. Soc. Rev. 2014, 43, 4751-4777. [CrossRef]

7. Mansour, A.M.; Abdel-Ghani, N.T. Synthesis, spectroscopic, DFT, cytotoxicity and antimicrobial activity of Pd(II) and Pt(II) complexes of N,N-chelated benzimidazole derivatives. Inorg. Chim. Acta 2015, 438, 76-84. [CrossRef]

8. Szucova, L.; Travnicek, Z.; Zatloukal, M.; Popa, I. Novel platinum(II) and palladium(II) complexes with cyclin-dependent kinase inhibitors: Synthesis, characterization and antitumour activity. Bioorg. Med. Chem. 2006, 14, 479-491. [CrossRef]

9. Alam, M.N.; Huq, F. Comprehensive review on tumor active palladium compounds and structure-activity relationships. Coord. Chem. Rev. 2016, 316, 36-67. [CrossRef]

10. Muralisankar, M.; Sujith, S.; Bhuvanesh, N.S.P.; Sreekanth, A. Synthesis and crystal structure of new monometallic and bimetallic copper(II) complexes with N-substituted isatin thiosemicarbazone ligands: Effects of the complexes on DNA/protein-binding property, DNA cleavage study and in vitro anticancer activity. Polyhedron 2016, 18, 103-117. [CrossRef]

11. Muralisankar, M.; Haribabu, J.; Bhuvanesh, N.S.P.; Karvembu, R.; Sreekanth, A. Synthesis, X-ray crystal structure, DNA/protein binding, DNA cleavage and cytotoxicity studies of N(4) substituted thiosemicarbazone based copper(II)/nickel(II) complexes. Inorg. Chim. Acta 2016, 449, 82-95. [CrossRef]

12. Kumar, A.; Naaz, A.; Prakasham, A.P.; Gangwar, M.K.; Butcher, R.J.; Panda, D.; Ghosh, P. Potent anticancer activity with high selectivity of a chiral palladium N-Heterocyclic Carbene Complex. ACS Omega 2017, 2, 4632-4646. [CrossRef] [PubMed]

13. Ray, S.; Mohan, R.; Singh, J.K.; Samantaray, M.K.; Shaikh, M.M.; Panda, M.D.; Ghosh, P. Anticancer and antimicrobial metallopharmaceutical agents based on palladium, gold, and silver N-heterocyclic carbene complexes. J. Am. Chem. Soc. 2007, 129, 15042-15053. [CrossRef] [PubMed]

14. Sharma, N.K.; Ameta, R.K.; Singh, M. Biological impact of Pd(II) complexes: Synthesis, spectral characterization, in vitro anticancer, CT-DNA binding, and antioxidant activities. Int. J. Med. Chem. 2016, 2016, 9245619. [CrossRef]

15. Ulukaya, E.; Ari, F.; Dimas, K.; Ikitimur, E.I.; Guney, E.; Yilmaz, V.T. Anti-cancer activity of a novel palladium(II) complex on human breast cancer cells in vitro and in vivo. Eur. J. Med. Chem. 2011, 46, 4957-4963. [CrossRef] [PubMed]

16. Graham, R.D.; Williams, D.R. The synthesis and screening for anti-bacterial, -cancer, -fungicidal and -viral activities of some complexes of palladium and nickel. J. Inorg. Nucl. Chem. 1979, 41, 1245-1249. [CrossRef]

17. Gao, E.; Liu, C.; Zhu, M.; Lin, H.; Wu, Q.; Liu, L. Current development of Pd(II) complexes as potential antitumor agents. Anti-Cancer Agents Med. Chem. 2009, 9, 356-368. [CrossRef]

18. Ng, H.L.; Ma, X.; Chew, E.H.; Chui, W.K. Design, synthesis, and biological evaluation of coupled bioactive scaffolds as potential anticancer agents for dual targeting of dihydrofolate reductase and thioredoxin reductase. J. Med. Chem. 2017, 60, 1734-1745. [CrossRef]

19. Shah, D.R.; Modh, R.P.; Chikhalia, K.H. Privileged s-triazines: Structure and pharmacological applications. Future Med. Chem. 2014, 6, 463-477. [CrossRef]

20. Liu, B.; Sun, T.; Zhou, Z.; Du, L. A systematic review on antitumor agents with 1,3,5-triazines. Med. Chem. 2015, 5, 131-148. [CrossRef] 
21. Barakat, A.; El-Senduny, F.F.; Almarhoon, Z.; Al-Rasheed, H.H.; Badria, F.A.; Al-Majid, A.M.; El-Faham, A. Synthesis, X-ray crystal structures, and preliminary antiproliferative activities of new s-triazine-hydroxybenzylidene hydrazone derivatives. J. Chem. 2019, 2019, 9403908. [CrossRef]

22. El-Faham, A.; Soliman, S.M.; Ghabbour, H.A.; Elnakady, Y.A.; Mohaya, T.A.; Siddiqui, M.R.; Albericio, F. Ultrasonic promoted synthesis of novel s-triazine-Schiff base derivatives; molecular structure, spectroscopic studies and their preliminary antiproliferative activities. J. Mol. Struct. 2016, 1125, 121-135. [CrossRef]

23. Soliman, S.M.; Elsilk, S.E.; El-Faham, A. Synthesis, structure and biological activity of zinc(II) pincer complexes with 2,4-bis(3,5dimethyl-1H-pyrazol-1-yl)-6-methoxy-1,3,5-triazine. Inorg. Chimica Acta 2020, 508, 119627. [CrossRef]

24. Soliman, S.M.; Elsilk, S.E.; El-Faham, A. Syntheses, structure, Hirshfeld analysis and antimicrobial activity of four new Co(II) complexes with s-triazine-based pincer ligand. Inorg. Chimica Acta 2020, 510, 119753. [CrossRef]

25. Soliman, S.M.; El-Faham, A.; Elsilk, S.E. Novel one-dimensional polymeric $\mathrm{Cu}(\mathrm{II})$ complexes via $\mathrm{Cu}$ (II)-assisted hydrolysis of the 2,4-bis(3,5-dimethyl-1H-pyrazol-1-yl)-6-methoxy-1,3,5-triazine pincer ligand: Synthesis, structure, and antimicrobial activities. Appl. Organomet. Chem. 2020, 34, e5941. [CrossRef]

26. Soliman, S.M.; Almarhoon, Z.; El-Faham, A. Synthesis, molecular and supramolecular structures of new Cd(II) pincer-type complexes with s-triazine core ligand. Crystals 2019, 9, 226. [CrossRef]

27. Soliman, S.M.; Almarhoon, Z.; Sholkamy, E.N.; El-Faham, A. Bis-pyrazolyl-s-triazine Ni(II) pincer complexes as selective gram positive antibacterial agents; synthesis, structural and antimicrobial studies. J. Mol. Struct. 2019, 1195, 315-322. [CrossRef]

28. Soliman, S.M.; El-Faham, A. Synthesis, X-ray structure, and DFT studies of five- and eight-coordinated Cd(II) complexes with s-triazine N-pincer chelate. J. Coord. Chem. 2019, 72, 1621-1636. [CrossRef]

29. Soliman, S.M.; El-Faham, A. Synthesis, molecular structure and DFT studies of two heteroleptic nickel(II) s-triazine pincer type complexes. J. Mol. Str. 2019, 1185, 461-468. [CrossRef]

30. Soliman, S.M.; El-Faham, A. One pot synthesis of two Mn(II) perchlorate complexes with s-triazine NNN-pincer ligand; molecular structure, Hirshfeld analysis and DFT studies. J. Mol. Str. 2018, 1164, 344-353. [CrossRef]

31. Soliman, S.M.; El-Faham, A. Synthesis, characterization, and structural studies of two heteroleptic Mn(II) complexes with tridentate $N, N, N$-pincer type ligand. J. Coord. Chem. 2018, 71, 2373-2388. [CrossRef]

32. Khripun, A.V.; Haukka, M.; Kukushkin, V.Y. Directed synthesis of isomerically pure platinum pyrazole complexes. Russ. Chem. Bull. Int. Ed. 2006, 55, 247-255. [CrossRef]

33. Otwinowski, Z.; Minor, W. Processing of X-ray diffraction data collected in oscillation mode. In Methods in Enzymology; Carter, C.W., Jr., Sweet, R.M., Eds.; Academic Press: New York, NY, USA, 1997; Volume 276, pp. 307-326.

34. Sheldrick, G.M. SADABS-Bruker Nonius scaling and absorption correction. J. Appl. Cryst. 2015, 48, 3-10.

35. Sheldrick, G.M. SHELXT-Integrated space-group and crystal-structure determination. Acta Cryst. 2015, A71, 3-8. [CrossRef]

36. Shedrick, G.M. Crystal structure refinement with SHELXL. Acta Cryst. 2015, C71, 3-8.

37. Turner, M.J.; McKinnon, J.J.; Wolff, S.K.; Grimwood, D.J.; Spackman, P.R.; Jayatilaka, D.; Spackman, M.A. Crystal Explorer17, University of Western Australia. 2017. Available online: http:/ / hirshfeldsurface.net (accessed on 10 July 2019).

38. Frisch, M.J.; Trucks, G.W.; Schlegel, H.B.; Scuseria, G.E.; Robb, M.A.; Cheeseman, J.R.; Scalmani, G.; Barone, V.; Mennucci, B.; Petersson, G.A.; et al. Gaussian, Inc.: Wallingford CT, UK, 2009.

39. Chai, J.D.; Head-Gordon, M. Long-range corrected hybrid density functionals with damped atom-atom dispersion corrections. Phys. Chem. Chem. Phys. 2008, 10, 6615-6620. [CrossRef]

40. Adamo, C.; Barone, V. Exchange functionals with improved long-range behavior and adiabatic connection methods without adjustable parameters: The $m$ PW and $m$ PW1PW models. J. Chem. Phys. 1998, 108, 664-675. [CrossRef]

41. Available online: https://bse.pnl.gov/bse/portal (accessed on 10 July 2019).

42. Feller, D. The role of databases in support of computational chemistry. J. Comp. Chem. 1996, 17, 1571-1586. [CrossRef]

43. Schuchardt, K.L.; Didier, B.T.; Elsethagen, T.; Sun, L.; Gurumoorthi, V.; Chase, J.; Li, J.; Windus, T.L. Basis set exchange: A community database for computational sciences. J. Chem. Inf. Model. 2007, 47, 1045-1052. [CrossRef]

44. Glendening, E.D.; Reed, A.E.; Carpenter, J.E.; Weinhold, F. NBO Version 3.1, CI; University of Wisconsin: Madison, WI, USA, 1998.

45. Abutaha, N.; Nasr, F.A.; Mohammed, A.Z.; Semlali, A.; Al-Mekhlafi, F.A.; Wadaan, M.A. Calendula arvensis L. as an anti-cancer agent against breast cancer cell lines. Mol. Biol. Rep. 2019, 46, 2187-2196. [CrossRef]

46. Martin, F.; Zipse, H. Charge distribution in the water molecule-A comparison of methods. J. Comput. Chem. 2005, 26, 97-105. [CrossRef] [PubMed]

47. Teixeira, F.; Mosquera, R.; Melo, A.; Freire, C.; Natalia, M.; Cordeiro, D.S. Charge distribution in Mn(salen) complexes. Int. J. Quant. Chem. 2014, 114, 525-533. [CrossRef]

48. Marques, M.P.M. Platinum and palladium polyamine complexes as anticancer agents: The structural factor. ISRN Spectrosc. 2013, 2013, 287353. [CrossRef]

49. Garoufis, A.; Hadjikakou, S.K.; Hadjiliadis, N. Palladium coordination compounds as anti-viral, anti-fungal, anti-microbial and anti-tumor agents. Coord. Chem. Rev. 2009, 253, 1384-1397. [CrossRef]

50. Czarnomysy, R.; Radomska, D.; Muszyńska, A.; Hermanowicz, J.M.; Prokop, I.; Bielawska, A.; Bielawsk, K. Evaluation of the anticancer activities of novel transition metal complexes with berenil and nitroimidazole. Molecules 2020, 25, 2860. [CrossRef] [PubMed] 